\title{
The Influences of Solvency, Cash Flow Ratio and Profitabiliy toward Going Concern Opinion
}

\author{
Ery Yanto \\ erymulyadi@yahoo.com \\ Accounting Study Program,Faculty of Business, \\ Presiden University, Cikarang, Indonesia \\ Pandu Adi Cakranegara \\ pandu.cakranegara@president.ac.id \\ Management Study Program, Faculty of Business, \\ President University, Ciakarang, Indonesia
}

\begin{abstract}
In providing an audit opinion, some assumptions must be met, one of which is that it will continue. In terms of corporate sustainability accounting, this is called a going concern. To evaluate whether the company has a going concern, an auditor can look at several indicators. These indicators include solvency, cash flow, and profitability. This study attempts to investigate the effect of these three variables towards audit going concern. Multiple linear regression statistical methods are used to link them with the going concern level. Based on the research results on 56 companies listed on the Indonesia Stock Exchange from 2017 to 2019 , it can be concluded that solvency, cash flow, and profitability significantly affect the company.
\end{abstract}

Keywords: going concern; solvency; cash flow; profitability

\begin{abstract}
Abstrak
Dalam memberikan audit opini ada asumsi yang harus dipenuhi, salah satunya adalah perusahaan akan tetap berlanjut. Dalam istilah akuntansi kesinambungan perusahaan ini disebut going concern. Untuk mengevaluasi apakah perusahaan memiliki going concern seorang auditor dapat melihat ke beberapa indikator. Indikator tersebut antara lain adalah solvency, cash flow dan profitability. Penelitian ini mencoba untuk mengetahui pengaruh ketiga variable tersebut terhadap audit going concern.Untuk menghubungkan antara variable-variabel tersebut dengan tingkat going concern, digunakan metode statistik regresi linear berganda. Berdasarkan hasil penelitian terhadap 56 perusahaan yang terdaftar di Bursa Efek Indonesia pada tahun 2017 hingga 2019 dapat ditarik kesimpulan bahwa solvency, cash flow dan profitability berpengaruh signifikan terhadap going concern perusahaan.
\end{abstract}

Kata kunci: going concern; sovabilitas; arus kas; profitabilitas 


\section{INTRODUCTION}

The factors that influence the audit opinion can be seen from several sides. Widayanto et al. (2020) examined the relationship between strategy and going concern factors. The assumption is that if the company's strategic plan can be implemented, the company will have a sustainable income source in the future. If the company has a sustainable income source, it means that the company has a going concern.

Radi et al. (2020) linked the company's size and the company's level of going concerned. Larger companies have a better-going concern level. However, the company's size can be related to various factors, such as a more professional management factor that can raise the company.

A larger company can employ professional management so that the company has a better level of going concerned.

Ulva and Suryani (2020) examined the previous year's opinion ongoing concern opinion. His research results indicate that the going concern opinion in the previous year affects the going concern opinion in the following year. This relationship is possible because going concern opinion related to long-term obligations and the company's ability to pay is not lost in a short time. This relationship means that a going concern opinion should not change within one year.

Oktaviani and Challen (2020) examined the effect of the default on going-concern opinion. The use of this default indicator can be an indicator to influence going concern opinion. Of course, companies that are threatened with default will also find it challenging to maintain their going concerns.

Companies are founded to make a profit. In the process, however, the company may become too focused on creating the maximum profit. Pressure on management to create makes management take short-term, profit-maximizing decisions. This decision has a trade off on the company's long-term prospects. Meanwhile, investors have a long-term perspective. Investors assess a company from the present value of cash flows that the company will generate in the future. This means that investors' valuations will only be realized if the company can realize cash flows in the future. If the company stops operating in the short term, the investor's valuation will not materialize because there is no realization of the company's future cash flows. Therefore, in auditing a company an auditor also pays attention to the sustainability of the company (Arens et al, 2012).

In determining a going concern opinion, several criteria are used. One of them is the company's ability to generate profits and the company's ability to maintain that profit in the future. This study examines the effect of company profits to see the company's ability to generate short-term profits (Shim \& Lansner, 2000). Meanwhile, the solvency variable is used to see the company's ability to meet its long-term obligations. Meanwhile, the cash flow ratio is used to see whether the company is able to generate real cash flow and not only accrual earnings.

The author's hope is that this research can provide information to the auditor regarding the variables that can determine the sustainability of the company which is the basis for providing a going concern audit opinion. For investors, this research is useful in providing investors with criteria that can be used to see which companies are suitable for long-term investment. In addition, this research can enrich the audit literature in Indonesia.

Unlike previous studies that used default indicators, this study uses indicators that can also see the company's ability to meet its short-term obligations. The assumptions used in this research are that the company will not experience default immediately but will experience a decline in the ability to pay its obligations continuously and then experience default. This assumption is reflected in the variables used in this study, namely solvency, cash flow, and 
profitability. The company can pay its long-term obligations if it has sufficient cash flow and cash flow is available if it has positive profitability. The hope is that by using indicators that reflect the ability to meet long-term obligations, auditors can see a decline in the company's ability to meet its long-term obligations earlier. This study seeks to build a model that hopes to provide a kind of early warning system for auditors so that auditors do not need to look at default indicators that tend to be close to the company's inability to fulfill their obligations.

This study aims to provide an alternative indicator that can examine the factors that influence a going concern. It is expected that by using the multiple linear regression statistical method, it can be seen which factors have a significant relationship with the company's going concern. Thus the auditor will have a theoretical guide to assess the company. In practical terms, this will provide a better understanding of the company's auditors is going concern capacity.

The purpose of this research is to find the factors that influence going concern. Furthermore, these factors can be used as indicators to assess a going concern. In the future, auditors can use these factors as indicators to assess going concern and the existing alternative indicators.

\section{LITERATURE REVIEW}

\section{Agency Theory}

This is the second part of the article. Try to analyse and discuss the extant literature by using relevant, updated theories and evidence. Use primary sources (article) from reputable journals.

The company's management uses capital from third parties from both banking and capital markets. The capital market has the advantage because the funds provided can have a cheaper cost because they come directly from investors without intermediaries. To raise funds from capital market investors, companies first need to be listed on the stock exchange. When companies raise funds from third parties, agency theory emerges. Agency theory arises because of a conflict of interest between the owner of the capital who is an external party investing the funds and the management who manages the fund. The party who manages the fund has an incentive to use the fund for the personal benefit of the manager, while investors want the maximum return.

To resolve this conflict of interest, several control mechanisms were created. One of these mechanisms is by examining the financial statements reported by management or what is also known as a financial report audit.

\section{Audit Opinion}

An audit of financial statements is carried out by an independent third party, in this case a public accountant. The appointment of a public accountant is carried out by the commissioner who represents the investor. The public accountant then checks the financial statements and provides reports to shareholders. The output of the audit is an audit opinion. Audit opinion has a level starting from the highest opinion, which is fair without exception, that is, when the company's financial statements describe the company's operations fairly both as a whole and at the account level. An opinion that is lower than an unqualified opinion is a fair opinion with a special note where in general the report shows the company's fair operations but there are several things in one or more accounts that are not in accordance with the applicable audit standards. Meanwhile, an unfair audit opinion indicates that management's financial reports are of low quality. The lowest opinion that can be given by the auditor is not giving an 
opinion where the auditor refuses to give an opinion because the company's financial statements are not made in accordance with generally accepted accounting standards.

\section{Going Concern}

An audit opinion can only be given by the auditor if the auditor has assessed that the company has a viability. Therefore, apart from ensuring that the financial statements are prepared based on applicable accounting standards, the auditor must also assess whether the company has the ability to maintain its operations. Manni and Faccia (2020) state that investors have hopes that their investment can provide returns. These returns will be realized if the company has enough time to collect profits. If the company cannot operate in the long term or will default soon, then, of course, the company cannot carry out its obligations. Furthermore, investors as recipients of residual returns will have the highest risk. Therefore, investors need to invest in a business that has a reasonable going concern.

\section{Going Concern Opinion}

As a form of auditor's responsibility, the auditor presents the company's sustainability report in the audit report. The company's sustainability report is presented in the form of a descriptive sentence which states that the company has the ability to continue its operations in a sustainable manner in the future. If the auditor has any doubts regarding the sustainability of the company, the auditor must state it and ask management to provide answers to the auditor's doubts. Xu and Kalkar (2020) state that an auditor's error in determining a going concern opinion will cause investors to make wrong decisions and cause losses. From that idea, going concern deserves to be one of the continuously researched factors in dynamic business conditions.

\section{Solvency}

One of the ratios that can be used by auditors to assess the sustainability of a company is by using a solvency ratio. The solvency ratio shows the company's ability to meet its longterm obligations. Li et al (2016) in their research show that the solvency ratio can be used as an indicator of company sustainability. This is because to fulfill long-term obligations, the company must be able to allocate part of its profits continuously to fulfill its obligations (Kenton \& Kindness, 2020). Therefore, the first hypothesis in this study is the solvency ratio has a positive effect on going-concern opinion.

\section{$H_{1}$ : Solvency has positive influence toward going concern opinion}

\section{Cash Flow Ratio}

The second indicator used is the cash flow ratio. The cash flow ratio shows how much real cash flow the company actually generates. This cash flow has several functions. The first function is the short-term function, which consists of fulfilling the company's short-term obligations and to provide returns for investors. The second function of cash flow is that a portion of the cash flows will be set aside by management to meet long-term liabilities. If the cash flow generated by investors is not sufficient, the cash flow can only be used to meet short-term obligations and cannot be allocated to meet the company's long-term obligations. Previous research from Safia (2014) shows that there is a significant positive relationship between the cash flow generated by the company and going concern opinion.

\section{$\mathrm{H}_{2}$ : Cash flow has positive influence toward going concern opinion}




\section{Profitability}

The third indicator used is the profitability indicator which is represented by the profitability ratio. The company aims to create profits and when the company is able to create profits according to investor expectations, the company is in a healthy condition (Shim \& Lansner, 2000). However, previous research from Li et al (2016) did not find a significant positive influence between the company's ability to generate profits and going concern opinion.

\section{$H_{3}:$ Profitability has positive influence toward going concern opinion}

\section{Theoretical Framework}

This study uses a sample as material for data processing. Samples were taken using the stratified sampling method in which samples were taken stratified based on the criteria placed. The first criterion is that the company selected is a company listed on the Indonesia Stock Exchange from 2017 to 2019 . The second criterion is a company that is a company that is included in the manufacturing category. The third criterion is companies that fall into the consumer goods manufacturing category.

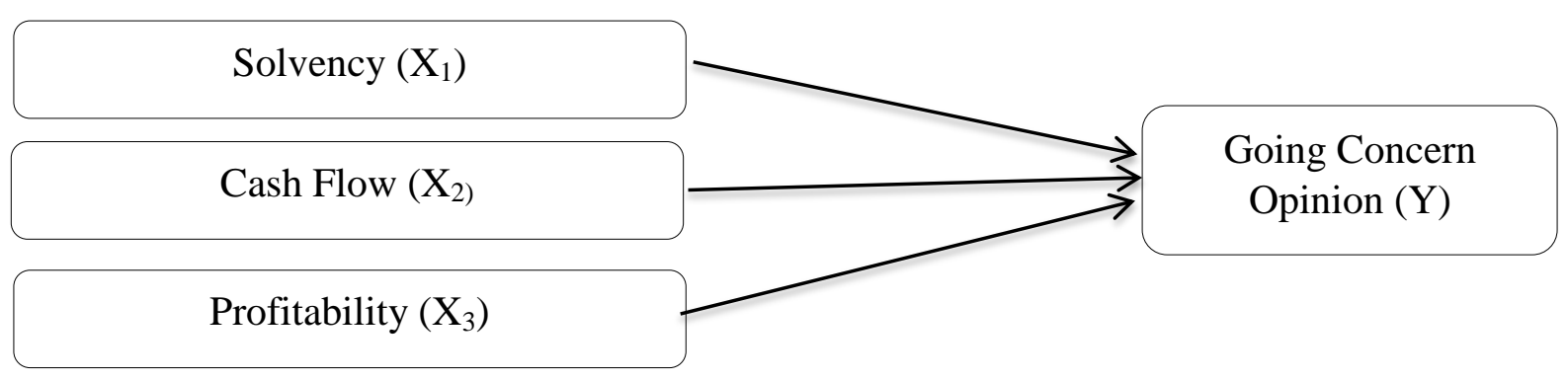

\section{Figure 1. Research Framework}

Source: Author, 2021

\section{RESEARCH METHOD}

\section{Population and Sample}

This research is a quantitative study using statistical methods. The statistical method used is multiple linear regression. The regression method helps connect the indicators in the financial statements with going concern opinion. The expected output of the regression method is to provide a significant level of financial statement indicators. By using the level of significance, it can be seen that variables that have a significant relationship and variables that do not have a significant relationship.

The population of this study is all companies listed on the Indonesia Stock Exchange. The choice of companies listed on the stock exchange is because companies listed on the stock exchange must provide regular financial reports to the stock exchange regulator. A public accountant must audit these financial statements.

The sampling method used was the purposive sampling method, namely the sampling method by determining predetermined criteria. The first thing to do is choose an industry. Industry selection needs to be done because each industry has its uniqueness so that the same indicator can have different effects when applied to different industries. The manufacturing industry was chosen because long-term debt in the manufacturing industry was used to fund long-term assets. These long-term assets are usually productive assets that are used for the 
company's core operations. Thus, the manufacturing company can be connected between taking long-term debt and company operations and then going concern opinion.

The second thing to do is select companies in the manufacturing industry that have a going concern opinion. The samples chosen were companies with a going concern opinion during the study period, namely 2017 to 2019. These two things were the criteria for determining the sample. Companies that meet both criteria are then used as research samples.

\section{Variable Measurement}

This research uses multiple linear regression method. This method has two variables, namely the dependent variable which is influenced by the independent variable. The independent variables consist of three, namely solvency, cash flow, and profitability. The dependent variable of this study is a going concern opinion.

The variables in this study consisted of the dependent variable and the independent variable. The dependent variable is the variable under study. In this case, the dependent variable is a going concern opinion. The independent variable consists of three variables. The first independent variable is solvency which is measured using the ratio of debt to equity. The second independent variable is the company's cash flow taken from the cash flow statement on its financial statements. The third variable is the company's profitability, which is represented by Net Income.

Table 1. Variable Measurement

\begin{tabular}{cccc}
\hline & Variable & Indicator & Scale \\
\hline $\mathrm{Y}$ & Going Concern & Going Concern coded 1 & \\
$\mathrm{X}_{1}$ & Opinion & Non Going Concern coded 0 & Interval \\
& & Debt/Equity & Ratio \\
$\mathrm{X}_{2}$ & Cash Flow & Operating Cash Flow/Current & \\
$\mathrm{X}_{3}$ & Profitability & Ratio & Ratio \\
\hline
\end{tabular}

Source: Author, 2021

\section{Data Analysis}

The data to be processed must be prepared in advance to be processed using multiple linear regression methods. As material for multiple linear regression, the data must meet several criteria, namely normality criteria, and through heteroscedascity, autocorrelation and multicolliniearity tests. After the data meets all these criteria, the data will be processed using multiple linear regression (Ghozali, 2018). The output of the multiple linear regression method is the level of relationship between the independent and dependent variables partially and the level of the relationship between the variables as a whole.

\section{Logistic Regression Model}

In particular, the multiple linear regression method used in this study is the logistic multiple linear regression method. The logistic method was chosen because the variables of this study were ordinal (Hair, 2015). The relationship between variables is illustrated below.

$$
Y_{i}=\beta_{0}+\beta_{1} X_{1, i}+\beta_{2} X_{2, i}+\beta_{3} X_{3, i}+\varepsilon_{1 i}
$$

Where

$$
\text { Y : Going Concern Opinion }
$$


$\mathrm{X}_{1}$ : Solvency

$\mathrm{X}_{2}$ : Cash Flow

$\mathrm{X}_{3}$ : Profitability

\section{RESULTS AND DISCUSSION}

\section{Sampling Process}

Table 2 shows the sampling process in this study. Samples were taken in stages according to the data criteria to be used. Of the total population, 56 companies were selected as the sample used in this study.

Table 2. Research Sample

\begin{tabular}{lc}
\hline \multicolumn{1}{c}{ Sample Criteria } & No. of Company \\
\hline Total Manufacturing Company 2017 -2019 & 193 \\
Total Manufacturing Consumer Company & 139 \\
Total Sample & 56 \\
\hline Source: Author, 2021 &
\end{tabular}

Table 2 shows the frequency of going concern opinions given by the auditor. Going concern opinion is only given by the auditor to companies which according to the auditor have an adequate level of business continuity. So that not all companies will get a going concern opinion.

\section{Variable Measurement}

This research uses multiple linear regression method. This method has two variables, namely the dependent variable which is influenced by the independent variable. The independent variables consist of three, namely solvency, cash flow, and profitability. The dependent variable of this study is a going concern opinion.

Table 3. Descriptive Statistics

\begin{tabular}{cccccc}
\hline Variable & $\mathrm{N}$ & Minimum & Maximum & Mean & Standard Deviation \\
\hline Solvency & 168 & $-2,890$ & 14,691 & 1,000 & 2,089 \\
Cash Flow & 168 & $-1,526$ & 3,073 & 0,410 & 0,733 \\
Profitability & 168 & $-223,564$ & 73,006 & 5,552 & 25,863
\end{tabular}

Source: Author, 2021

\section{Coefficient of Determination}

Table 4. Coefficient of Determination

\begin{tabular}{cccc}
\hline Step & $\begin{array}{c}\text { 2-log } \\
\text { Likelihood }\end{array}$ & $\begin{array}{c}\text { Cox \& Snell } \\
\text { R Square }\end{array}$ & $\begin{array}{c}\text { Nagelkerke R } \\
\text { Square }\end{array}$ \\
\hline 1 & 108,367 & 0,326 & 0,504 \\
\hline
\end{tabular}

Source: Author, 2021 
The coefficient of determination in table 4 serves to show the suitability of the model built in this study. The number 0.504 shows that the three independent variables in this study are simultaneously able to explain the emergence of more than fifty percent of the going concern opinion.

However, the coefficient of determination does not provide information about which independent variables in the model affect the dependent variable. The coefficient of determination also does not inform the level of significance of the independent variable. Therefore it is necessary to carry out further tests to obtain information, namely by doing a partial t test.

\section{Hypothesis Test}

The statistical test that can be used to test the effect of individual independent variables on the dependent variable is the partial $t$ test. The results of the partial $t$ test are shown in table 4.9.

Table 5. Logistic Regression Testing

\begin{tabular}{cccll}
\hline Variable & $\beta$ & Wald & Significance & Decision \\
\hline Constant & $-3,285$ & 23,734 & 0,037 & \\
$\mathrm{X}_{1}$ & 1,776 & 4,441 & 0,035 & $\mathrm{H}_{1}$ supported \\
$\mathrm{X}_{2}$ & 1,110 & 10,397 & 0,000 & $\mathrm{H}_{2}$ supported \\
$\mathrm{X}_{3}$ & 0,114 & 19,269 & 0,000 & $\mathrm{H}_{3}$ supported \\
\hline
\end{tabular}

Source: Author, 2021

$$
Y_{i}=-3,285+1,776 \text { Solvency }+1,110 \text { Cash Flow }+0,114 \text { Profitability }
$$

From the results of the t test processing, there are three significant variables. The three variables are solvency, cash flow and profitability. The results of the t test indicate that all independent variables have a significant and positive effect on the dependent variable.

From the three variables, it can be seen that the solvency variable has the greatest influence. Every one percent increase in the solvency variable will increase the probability to get going-concern opinion by 1.776 percent. Meanwhile, cash flow has the second biggest influence where every one percent increase in cash flow will increase the probability to get going concern opinion by 1.11 or higher than one percent. Meanwhile, a one percent increase in the profitability variable only has an effect of 0.114 percent on going concern opinion

\section{Managerial Conclusions}

This research is consistent with previous research from Widayanto et al. (2020), Redi et al.. Ulva and Suryani (2020) state that this study's long-term obligations are represented by the solvency variable, which can show a tendency for going concern opinions given by auditors. This study also shows that debt default does not occur suddenly but through a process that starts with the decline in company profitability to affect the cash flow used to pay its liabilities.

This research's contribution is that by looking at the affected indicators earlier, the auditor can estimate how the company's position is. It may be that the company is still able to fulfill its obligations, but if viewed from the cash flow indicator and profitability, the trend will decline further in the future. Alternatively, in other words, the company does not need to wait until signs that the company will default on its debt or appear. 
For investors, these findings will provide an indicator to predict the level of going concern in the future. Investors who can predict faster will be able to anticipate in advance than investors who do not have the same predictive ability.

The statistical results show that the three independent variables in this study have a significant effect on the dependent variable. This is in accordance with previous research. The findings of this study are that solvency is the best indicator of the three indicators in this study. Meanwhile, profitability is the smallest indicator in determining a going concern opinion.

The consequence of this finding is that auditors cannot only use profitability indicators such as net income to determine the company's going concern. There is no guarantee that these profits will be sustainable in the long run. Therefore, to assess the long-term prospects of a company that must be considered is the company's long-term indicator. Thus, there is a matching principle, namely assessing long-term prospects using long-term indicators.

If the company has been able to set aside cash flow to meet long-term obligations, the company will have a good sustainability. Conversely, if the company is not able to set aside part of its cash flow and allocate it to meet long-term obligations, it could be that the company has problems in its sustainability.

Although the solvency indicator is not a perfect indicator that can definitely show the sustainability of the company, based on the results of the suitability of the model, the indicators in this model can explain most of the company's sustainability. This means that the three indicators in this study can be used by the auditor to determine a going concern opinion.

\section{CONCLUSION}

The results of this study indicate that partially there is an influence between the variable solvency, cash flow and profitability on going-concern opinion. While overall these three variables can be used to assess going-concern opinion on consumer goods manufacturing companies. However, seen from the R Square figure which is in the range of 0.5, it shows that there are still some other variables that affect going-concern opinion. Future research can look for other variables that affect going-concern opinion to add to the results of this study.

\section{REFERENCES}

Astuti, I. R., \& Darsono, D. (2012). Pengaruh faktor keuangan dan non keuangan terhadap penerimaan opini audit going concern (Doctoral dissertation, fakultas ekonomika dan bisnis).

Azizah, R., \& Anisykurlillah, I. (2014). Pengaruh ukuran perusahaan, debt default, dan kondisi keuangan perusahaan terhadap penerimaan opini audit going concern. Accounting analysis journal, 3(4).

Ghozali. (2018). Aplikasi analisis multivariate dengan IBM SPSS 25. Forum Ilmiah Pendidikan Akuntansi Universitas PGRI Madiun.

Hair, Jr, J. F. (2015). Essentials of business research methods. In Essentials of Business Research Methods. https://doi.org/10.4324/9781315704562

Kenton, W., \& Kindness, D. (2020). Solvency ratio definition. Investopedia.

Lie, C., Wardani, R. P., \& Pikir, T. W. (2016). Pengaruh likuiditas, solvabilitas, profitabilitas, dan rencana manajemen terhadap opini audit going concern (Studi empiris perusahaan manufaktur di BEI). Berkala Akuntansi Dan Keuangan Indonesia. 
https://doi.org/10.20473/baki.v1i2.2694

Manni, F., \& Faccia, A. (2020). The business going concern: financial return and social expectations. In Sustainable Development and Social Responsibility-Volume 1 (pp. 201-213). Springer, Cham.

Oktaviani, O., \& Challen, A. E. (2020). Pengaruh kualitas auditor, audit tenure dan debt default terhadap penerimaan opini audit going concern. Jurnal Akuntansi dan Keuangan, 8(2), 83-90.

Radi, D. O., Wijaya, S. Y., \& Julianto, W. (2020). Pengaruh ukuran perusahaan, masa audit dan gagal bayar terhadap opini audit going concern. Jurnal of Admiration, 1(7), 821834.

Safira Pramestri Ibrahim, R. (2014). Pengaruh Audit lag, rasio leverage, rasio arus kas, opini audit tahun sebelumnya dan financial distress terhadap penerimaan opini going concern. Jurnal Ekonomi Akuntansi.

Shim, J. K., \& Lansner, J. (2000). Profitability ratios. In 101 Investment Tools for Buying Low \& Selling High (pp. 227-233). CRC Press. https://doi.org/10.1201/9781420033106-14

Ulva, A., \& Suryani, E. (2020). Pengaruh audit tenure, debt default, dan opini audit tahun sebelumnya terhadap penerimaan opini audit going concern (Studi Pada sektor pertambangan yang terdaftar di bursa efek Indonesia periode 2014-2018). eProceedings of Management, 7(2).

Widayanto, M. T., Hermawan, D. J., \& Natsir, M. (2020). Implementasi manajemen strategik dan hubungannya dengan keberlangsungan (Going concern) Usaha. SKETSA BISNIS, 7(2), 72-83.

$\mathrm{Xu}, \mathrm{Q}$., \& Kalelkar, R. (2020). Consequences of going-concern opinion inaccuracy at the audit office level. Auditing: A Journal of Practice \& Theory, 39(3), 185-208. 